\title{
BMJ Open Prevalence and predictors of gestational diabetes mellitus in rural Assam: a cross-sectional study using mobile medical units
}

\author{
Subrata Chanda, ${ }^{1}$ Vishal Dogra (1) , ${ }^{2}$ Najeeb Hazarika, ${ }^{3}$ Hardeep Bambrah, ${ }^{3}$ \\ Ajit Kisanrao Sudke, ${ }^{4}$ Anupa Vig, ${ }^{4}$ Shailendra Kumar Hegde ${ }^{5}$
}

To cite: Chanda S, Dogra V, Hazarika N, et al. Prevalence and predictors of gestational diabetes mellitus in rural Assam: a cross-sectional study using mobile medical units. BMJ Open 2020;10:e037836. doi:10.1136/ bmjopen-2020-037836

- Prepublication history and additional materials for this paper is available online. To view these files, please visit the journal online (http://dx.doi org/10.1136/bmjopen-2020037836).

Received 19 February 2020 Revised 09 August 2020 Accepted 28 September 2020

Check for updates

(c) Author(s) (or their employer(s)) 2020. Re-use permitted under CC BY-NC. No commercial re-use. See rights and permissions. Published by BMJ.

For numbered affiliations see end of article.

Correspondence to

Vishal Dogra;

vani1825@gmail.com

\section{ABSTRACT}

Objective To determine the prevalence and predictors of gestational diabetes mellitus (GDM) in rural Assam, India using a network of Mobile Medical Units.

Study design A field-based cross-sectional study.

Settings Rural areas of Assam state, India.

Participants A total of 1410 pregnant women in gestational age of 24-28 weeks

Intervention Identification of pregnant women in 24-28 weeks of pregnancy from villages and administering them Government of India recommended oral glucose tolerance test for GDM confirmation.

Primary and secondary outcome measures Presence of gestational diabetes among pregnant women, risk factors and predictors of GDM.

Results A total of 1212 pregnant women underwent the oral glucose tolerance test. One hundred and ninety-eight women were ineligible due to existing chronic diseases or very high blood glucose level before the test. The overall GDM prevalence in Assam was $16.67 \%(95 \% \mathrm{Cl} 14.61 \%$ to $18.89 \%$ ). Women aged $26-30$ years (adjusted odds ratio, aOR 1.70; $\mathrm{Cl} 1.14$ to 2.52), who passed 10th class (aOR 1.58 ; $\mathrm{Cl} 1.05$ to 2.37 ), belonging to Muslim religion ( $\mathrm{aOR}$ $1.52 ; 95 \% \mathrm{Cl} 1.05$ to 2.21 ) and above poverty line (aOR $1.38 ; 95 \% \mathrm{Cl} 1.00$ to 1.91 ) had significantly increased likelihood of developing GDM compared with respective baseline groups $(p<0.05)$. Body mass index, gravida and being non-anaemic were non-significant risk factors for GDM. Family history of diabetes (aOR $1.82 ; 95 \% \mathrm{Cl} 1.08$ to 3.06 ) and smoking (aOR $1.61 ; 95 \% \mathrm{Cl} 1.10$ to 2.35 ) were significant and independent predictors of GDM.

Conclusion The prevalence of GDM in rural Assam is high. The mobile medical units may play a significant role in the implementation of GDM screening, diagnosis, treatment to ensure better maternal and foetal health outcomes in rural Assam.

\section{BACKGROUND}

Glucose intolerance or high blood sugar detected for the first time during pregnancy is known as gestational diabetes mellitus $(\mathrm{GDM}) .{ }^{1}$ Worldwide GDM is a significant public health problem. ${ }^{2}$ GDM both leads to adverse foetal health outcomes in the form of neonatal jaundice, stillbirths, macrosomia
Strengths and limitations of this study

The study used a representative sample of all eligible pregnant women in rural Assam.

- All eligible pregnant women underwent blood glucose estimation before initiating the oral glucose tolerance test.

- A standardised gold standard oral glucose tolerance test confirmed the presence of gestational diabetes mellitus among pregnant women.

- We could neither obtain a venous blood sample of pregnant women for glucose estimation nor test the blood glucose level early in pregnancy due to operational constraints.

and also affects maternal health. ${ }^{3}$ The GDM leads to maternal complications such as preeclampsia, the need for caesarean section and respiratory distress. ${ }^{4}$ Even GDM mother's risk of developing diabetes is up by $10 \%$ immediately after delivery. Evidence suggests that children born to GDM mothers are nearly four to eight times more likely to develop diabetes in later life compared with their siblings born to the same parent with no GDM. $^{5}$

GDM affects about 4 million women in India. The prevalence of GDM in the Indian population is high compared with other Asian countries. At any point in time, the GDM prevalence ranges from $6 \%$ to $9 \%$ in rural and $12 \%$ to $21 \%$ in the urban areas. ${ }^{6-8}$

The Government of India guidelines mandates age-appropriate GDM screening of pregnant women at primary health centres (PHCs) during regular antenatal check-ups (ANC).${ }^{9}$ However, due to infrequent glucose and insulin supply, and the non-availability of healthcare staff at primary public health facilities in most of the Indian states, GDM screening is not a regular part of ANC visits, results of which rural pregnant women are 
not timely screened and in some cases, leads to misdiagnosis of GDM among suspected pregnant women. ${ }^{10} 11$

The public health facilities and their problems are no different in the north-eastern Indian state of Assam. Issues like hilly and challenging terrain, poor health infrastructure and acute shortage of medical doctors at peripheral public health facilities contribute to inadequate or nonimplementation of different government health schemes including GDM screening. ${ }^{12}{ }^{13}$ Therefore, reliable GDM data and estimations for rural Assam are inadequately studied. A few research studies, with a limited sample, documented GDM prevalence in scattered rural geography of Assam but all such estimates are from hospitalbased studies and lack generalisability.

The state government of Assam runs a large mobile medical unit (MMU) programme to deliver basic primary health services to its rural population. The vast network of MMUs allows us both to study the pattern of healthcare morbidities among programme beneficiaries and provide a platform to routinely report and derive the population-based estimates on key health conditions. ${ }^{14} 15$ Evidence also suggests that MMUs are useful in screening of diseases like tuberculosis, breast cancer, HIV, hepatitis. ${ }^{16-18}$ Hence, we take the opportunity to leverage the MMU platform to reach and screen eligible pregnant women in rural Assam. We aim to determine the prevalence and associated risk factors of GDM in rural Assam.

\section{METHODS}

We did a cross-sectional study in rural Assam. We divided the state into five zones. Using multistage sampling, pregnant women in the gestational age of 24-28 weeks were identified. All eligible pregnant women were reached through MMUs in each zone and screened for GDM using the oral glucose tolerance test (OGTT) irrespective of fasting status.

\section{Study design}

Cross-sectional study.

\section{Setting and participants}

The north-eastern state of Assam has a population of 30.12 million with 993 females per 1000 males. ${ }^{19}$ As per recent rural health statistics, Assam has a shortfall of $21 \%$ of sub-centres (SCs), $1 \%$ of PHCs and $28 \%$ of community health centres against the sanctioned numbers. Access to $15 \%$ of SCs and $3.1 \%$ of PHCs is difficult due to the unavailability of roads. Nearly, $16.8 \%$ SCs are beyond $3 \mathrm{~km}$ radius of villages and $31.7 \%$ of PHCs are beyond $10 \mathrm{~km}$ radius of villages. ${ }^{20}$ People in rural Assam depends heavily on public health services $(82.7 \%)$. As of 2015-2017, Assam has the highest maternal mortality ratio (MMR) in the country at 229 deaths per 100000 live birth compared with India's MMR of 122. The state reports high infant mortality rate (44/1000 live births) compared with national averages (33/1000 live births). The incidence of non-communicable diseases is rising,
Table 1 Zone and district wise distributions of MMUs in rural Assam

\begin{tabular}{llll}
\hline Zones & Name of the districts & Districts (\#) & MMUs (\#) \\
\hline North & $\begin{array}{l}\text { Sonitpur, Dhemaji, } \\
\text { Lakhimpur, Darrang, } \\
\text { Nagaon }\end{array}$ & 5 & 15 \\
South & $\begin{array}{l}\text { Cachar, Karimganj, } \\
\text { Hailakandi, NC Hills }\end{array}$ & 4 & 17 \\
East & $\begin{array}{l}\text { Tinsukia, Dibrugarh, } \\
\text { Jorhat, Karbi angling, } \\
\text { Golaghat, Sivsagar }\end{array}$ & 6 & 17 \\
West & $\begin{array}{l}\text { Bongaigaon, Kokrajhar, } \\
\text { Dhubri, Barpeta, Chirang, } \\
\text { Goalpara }\end{array}$ & 17 \\
Central & $\begin{array}{l}\text { Kamrup, Udalguri, Baksa, } \\
\text { Nalbari, Morigaon }\end{array}$ & 12 \\
\hline
\end{tabular}

MMU, mobile medical unit.

especially diabetes and hypertension. As per National Family Health Survey-4, 5.2\% women and 6.6\% men have high blood sugar levels; $11.8 \%$ women and $15.1 \%$ men have raised blood pressure. ${ }^{21} 22$

\section{The MMU programme description}

The MMU programme, known as 'Sanjeevani,' in Assam state, is a public-private partnership between the Government of Assam and Piramal Swasthya Management and Research Institute (PSMRI). The programme scope is to provide promotive, preventive, curative and referral services to villagers at their doorstep for non-emergency primary health conditions such as seasonal illnesses and common diseases. The state government provides funds while PSMRI implements field services and run programme operations.

Sanjeevani is a nurse-led MMU programme, having a fleet of 78 MMUs and covers nearly $3744(14.4 \%)$ of all villages (26 000) across Assam state. Each MMU has a nurse, pharmacist, laboratory technician and a registration and measurement officer. Every MMU follows a fixed day service delivery schedule and visit a particular village once in a month for delivering health services.

The programme, for its operations, operates in five distinct zones of the state. Table 1 summarises the details of each zone and the numbers of MMUs. For study purpose, we refer to each zone as a cluster.

\section{Study duration}

Data were collected between July 2019 and September 2019.

\section{Outcome variable}

The presence or absence of GDM among pregnant women confirmed through OGTT is the primary study outcome. 


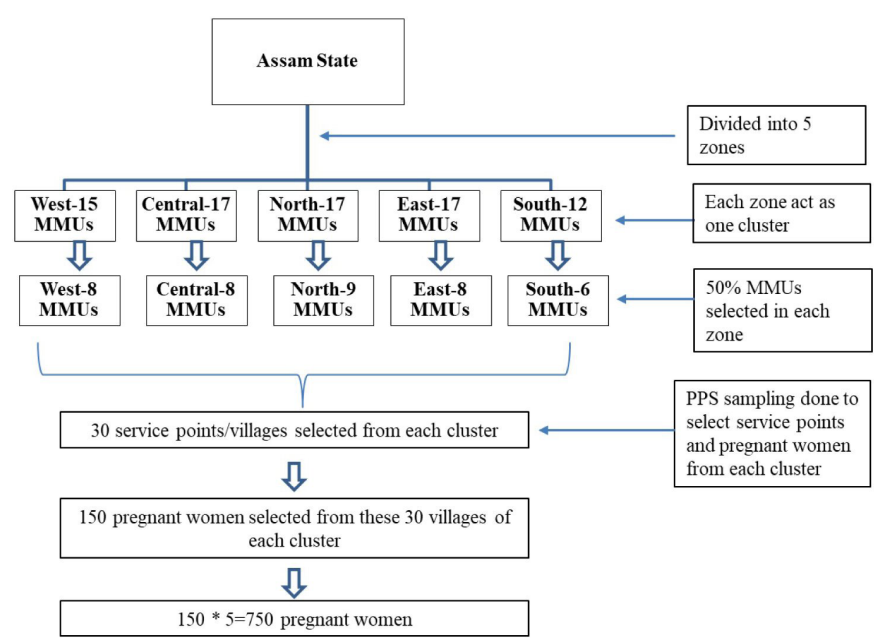

Figure 1 Sampling methodology. MMU, mobile medical unit.

\section{Independent variables}

Sociodemographic variables (age, religion, education and economic status), body mass index (BMI), blood pressure (systolic and diastolic), gravida status (primi and multigravida), haemoglobin levels (for anaemia status), family history of diabetes, miscarriage history, alcohol and tobacco use. The measurements of height, weight and blood pressure were taken through the standardised and calibrated equipment as per the WHO STEPwise approach to surveillance (STEPS) manual. ${ }^{23}$

\section{Sample size}

We calculated a minimum sample of 150 for each cluster considering the expected proportion of GDM 7\%, absolute precision $5 \%$, design defect 1.5 and a $95 \%$ CI.

We randomly selected $50 \%$ of the MMUs from each cluster. An MMU, on average, covers 48 villages (service delivery points) every month. From each cluster, we randomly selected 30 villages, using a probability proportional to size method. Next, we line listed all pregnant women in the gestational age of 24-28 weeks in the selected villages. However, to extend the benefit of GDM screening, all eligible women in 24-28 weeks of pregnancy were included in the study in the sampled villages. The random selection of MMUs and villages was done through a random numbers table. Figure 1 depicts the sampling methodology.

\section{Inclusion and exclusion criteria}

All pregnant women in the gestational age of 24-28 weeks were included. Pregnant women with known history of diabetes mellitus or GDM and other chronic illnesses such as cancer, hypertension, asthma, epilepsy and arthritis were excluded from the study. Pregnant women with blood random glucose level $>200 \mathrm{mg} / \mathrm{dL}$ before initiating OGTT were also excluded.

\section{GDM screening: the OGTT}

The study followed Ministry of Health and Family Welfare (MoHFW), Government of India's 'Technical and
Operational Guidelines for Diagnosis and Management of GDM', which are more relevant for Indian population. These guidelines took into consideration the recommendations of the county's subject experts available national and international evidences including the Diabetes in Pregnancy Study Group in India and WHO's (1999) GDM diagnostic criteria. ${ }^{9425}$

As per MoHFW guidelines, irrespective of the fasting status, all eligible women were asked to drink $75 \mathrm{~g}$ of anhydrous glucose dissolved in $300 \mathrm{~mL}$ of water over 5-10 min period. After 2 hours of glucose ingestion, we measured blood glucose levels using plasma calibrated glucometers. A blood sugar level equal to $140 \mathrm{mg} / \mathrm{dL}$ or higher indicates GDM. $^{9}$

All diagnosed positive cases were referred to the PHC Medical Officer (MO) to start the treatment immediately.

\section{Data collection}

The first step involved line listing of all 24-28 weeks gestation pregnant women in the selected villages. We used government provided 'Mother and Child Protection Card' issued to every pregnant mother to ascertain the last date of menstrual period and eligibility. In the next step, we identified a PHC nearest to at least two selected villages. Eligible pregnant women from these villages were then mobilised by a village health worker (Accredited Social Health Activist-ASHA) to a preidentified PHC. At PHC, two MMUs were on standby. Paramedical staff from one MMU helped PHC doctor in administering the OGTT and recording the results along with capturing other information using a data tool (see online supplemental annexure 1). The other MMU was used to transport all identified pregnant women to and from their homes.

We incentivised ASHAs @ $\$ 0.70$ (INR 50) per pregnant woman for mobilising a pregnant woman to respective health facilities. The presence of a MO helped in managing any emergency and initiating immediate treatment for GDM positive cases.

Data were collected from July to September 2019 using a survey tool.

\section{Data analysis}

Primary data were entered into excel and imported into STATA (V.15.1) for further analysis. ${ }^{26}$ Categorical data were presented as percentages $(\%)$ and Pearson's $\chi^{2}$ test was used to evaluate the difference in proportions. Logistic regression method established the independent associations between the outcome and the predictor variables giving ORs, $95 \%$ CIs and $p$ values.

\section{Patient and public involvement}

No patient or public members were involved in the design and execution of this study.

\section{RESULTS}

A total of 1410 women were eligible for the study of which 198 pregnant were suffering from chronic illnesses 
including diabetes or blood glucose level $>200 \mathrm{mg} / \mathrm{dL}$ before initiating OGTT, hence were excluded. We report the analysis of eligible 1212 pregnant women who underwent the OGTT.

The mean age of the study sample was 23.7 years $(\mathrm{SD} \pm 4.20)$ years. More than two-thirds $(70 \%)$ women were in 15-25 years age group. More than half $(55 \%)$ were Hindu, educated up to primary level $(50 \%)$ and belonging to below poverty line (74\%). Nearly one-third (32\%) had abnormal BMI, and very few were hypertensive $(3 \%)$. More than half $(51 \%)$ were already having three or more children. A large proportion of women were anaemic $(83 \%)$. A few women reported a family history of diabetes $(6 \%)$ or abortion $(7 \%)$ in their previous pregnancy. A few pregnant women were smokers $(2 \%)$ (table 2).

The GDM prevalence in rural Assam is $16.7 \%$ (range $12.9 \%-20.6 \%)$. The central zone has a higher GDM prevalence $(20.6 \%)$ compared with the other four zones (North-18.4\%; South-15.0\%; East-12.9\%; West-15.5\%). (table 3).

We found an increased likelihood of GDM with increasing age. Pregnant women (aged 26-30 years) were 1.7 times (adjusted odds ratio (aOR); 95\% CI) (aOR 1.7; $95 \%$ CI 1.14 to 2.52 ) more likely to have GDM compared with younger women $(15-20$ years $)(\mathrm{p}=0.01)$. Women who passed 10th class (aOR 1.58; CI 1.05 to 2.37), belonging to Muslim religion (aOR 1.52; 95\% CI 1.05 to 2.21 ) and above poverty line (APL; aOR 1.38; $95 \%$ CI 1.00 to 1.91) had significantly increased likelihood of developing GDM compared with respective baseline groups $(p<0.05)$. Gravida status, BMI and being non-anaemic were nonsignificant risk factors for GDM. Family history of diabetes (aOR 1.82; 95\% CI 1.08 to 3.06) and smoking (aOR 1.61; $95 \%$ CI 1.10 to 2.35 ) were significant and independent predictors of GDM (table 4).

\section{DISCUSSION}

Using a network of MMUs in rural Assam, we derived both the first-hand estimates of GDM prevalence and its relationship with sociodemographic and other risk and also assessed the feasibility of GDM screening in the community settings. In our study, the basic characteristics of GDM mothers and non-GDM mothers did not vary significantly (not shown in results) except for age, BMI, economic status and family history of diabetes.

The study sample consists of pregnant young, literate, Hindu and Muslim females which correspond to the latest population statistics of the state. ${ }^{27}$ We found GDM prevalence of $16.7 \%$ in rural Assam (range: 12.9\%$20.6 \%)$. Education (10th pass), age (26-30 years), religion (Muslim), socioeconomic status (APL), tobacco use (currently smokers) and past history (family history of diabetes) were the significant primary predictors of GDM in rural Assam. The GDM prevalence estimates, as found in our study, in rural Assam, are high compared with international and national evidence. For example,
Table 2 Basic characteristics of pregnant women according to GDM status in rural Assam (2019)

\begin{tabular}{|c|c|c|c|}
\hline & GDM (-) & GDM (+) & Total \\
\hline Variable & $n=1010(\%)$ & $\mathrm{n}=202(\%)$ & $n=1212(\%)$ \\
\hline Age (mean $\pm S D)$ & $23.5(4.04)$ & $24.4(4.6)$ & $23.7(4.2)$ \\
\hline \multicolumn{4}{|l|}{ Age categories } \\
\hline 15-20years & 291 (29) & $51(25)$ & $342(28)$ \\
\hline 21-25years & $437(43)$ & $71(35)$ & $508(42)$ \\
\hline 26-30years & $235(23)$ & $63(31)$ & $298(25)$ \\
\hline$>30$ years & $47(5)$ & $17(8)$ & $64(5)$ \\
\hline \multicolumn{4}{|l|}{ Religion } \\
\hline Hindu & $566(56)$ & $102(51)$ & $668(55)$ \\
\hline Muslim & $433(43)$ & $99(49)$ & $532(44)$ \\
\hline Christian & $11(1)$ & $1(1)$ & $12(1)$ \\
\hline \multicolumn{4}{|l|}{ Education } \\
\hline Illiterate & $71(7)$ & $10(5)$ & $81(7)$ \\
\hline Primary school & $516(51)$ & $93(46)$ & $609(50)$ \\
\hline 10th pass & $234(23)$ & $53(26)$ & $287(24)$ \\
\hline 12th pass & $136(14)$ & $31(15)$ & $167(14)$ \\
\hline $\begin{array}{l}\text { Graduate and } \\
\text { above }\end{array}$ & $53(5)$ & $15(7)$ & $68(6)$ \\
\hline \multicolumn{4}{|l|}{ Economic status } \\
\hline $\begin{array}{l}\text { Above poverty } \\
\text { line }\end{array}$ & $247(24)$ & $68(34)$ & $315(26)$ \\
\hline $\begin{array}{l}\text { Below poverty } \\
\text { line }\end{array}$ & $763(76)$ & $134(66)$ & $897(74)$ \\
\hline
\end{tabular}

Body mass index

\begin{tabular}{|c|c|c|c|}
\hline Normal & 700 (69) & $125(62)$ & $825(68)$ \\
\hline Underweight & $194(19)$ & $43(21)$ & $237(20)$ \\
\hline $\begin{array}{l}\text { Overweight/ } \\
\text { obese }\end{array}$ & $116(12)$ & $34(17)$ & $150(12)$ \\
\hline \multicolumn{4}{|c|}{ Blood pressure levels } \\
\hline Normal & $681(67)$ & $138(68)$ & $819(68)$ \\
\hline Prehypertension & $300(30)$ & $54(27)$ & $354(29)$ \\
\hline Hypertension & $29(3)$ & $10(5)$ & 39 (3) \\
\hline \multicolumn{4}{|l|}{ Gravida status } \\
\hline Primigravida & 499 (49) & $97(48)$ & 596 (49) \\
\hline Multigravida & $511(51)$ & $105(52)$ & $616(51)$ \\
\hline Anaemia (Y) & $846(84)$ & $156(77)$ & $1002(83)$ \\
\hline $\begin{array}{l}\text { Diabetes family } \\
\text { history }(Y)\end{array}$ & $51(5)$ & 24 (12) & $75(6)$ \\
\hline $\begin{array}{l}\text { Miscarriage } \\
\text { history }(Y)\end{array}$ & $70(7)$ & $19(9)$ & $89(7)$ \\
\hline $\begin{array}{l}\text { Current smoker } \\
\text { (Y) }\end{array}$ & $21(2)$ & $8(4)$ & $29(2)$ \\
\hline
\end{tabular}

GDM, gestational diabetes mellitus.

studies from Bangladesh, Egypt and Ethiopia reported prevalence rates of $9.7 \%, 8.0 \%$ and $7.7 \%$, respectively. ${ }^{28-30}$ Likewise, GDM prevalence ranges from $6 \%$ to $9 \%$ in 
Table 3 Prevalence of GDM (zone wise) in rural Assam, (2019)

\begin{tabular}{|c|c|c|c|c|}
\hline Zone & $\mathrm{N}$ & $\begin{array}{l}\text { GDM prevalence } \\
(\%)\end{array}$ & $95 \% \mathrm{Cl}$ & $P$ value \\
\hline North & 218 & 18.4 & 13.7 to 24.1 & \\
\hline South & 253 & 15.0 & 11.1 to 20.0 & \\
\hline Central & 282 & 20.6 & 16.2 to 25.7 & 0.18 \\
\hline East & 194 & 12.9 & 8.8 to 18.4 & \\
\hline West & 265 & 15.5 & 11.6 to 20.3 & \\
\hline Total & 1212 & 16.7 & & \\
\hline
\end{tabular}

North (Sonitpur, Dhemaji, Lakhimpur, Darrang, Nagaon), South (Cachar,Karimganj, Hailakandi, N C Hills), Central (Kamrup, Udalguri, Baksa, Nalbari,Morigaon), East (Tinsukia, Dibrugarh, Jorhat, Karbi angling, Golaghat) and West (Bongaigaon, Kokrajhar, Dhubri, Barpeta, Chirang, Goalpara). GDM, gestational diabetes mellitus.

rural India and remains high for rural Assam. ${ }^{7831-34}$ It is imperative to state that majorities of the Indian evidence come from studies done in North and South India. Studies from northeast India are scarce and primarily done under hospital settings. Evidence from these studies reports a low prevalence of GDM in the northeast region (Assam 3\%, Manipur 0\%-1\%,) compared with other states (Jammu and Kashmir 3.8\%-11\%; Maharashtra 0.5\%-9.5\%; Andhra Pradesh $17.20 \%-21.81 \%$ and Uttar Pradesh $13.38 \%-41.87 \%)$. Similarly, studies from rural and urban India found a considerable variation in GDM prevalence in rural $(0.5 \%-13.9 \%)$ and urban areas $(0.56 \%-41.9 \%)$, respectively. ${ }^{85} 36$

Geographically, the central zone districts had the highest GDM prevalence among all study zones. The geographical differences in prevalence in different regions are due to differences in the demographic and socioeconomic status of pregnant women in these regions. ${ }^{32}$ Studies show that the likelihood of GDM among pregnant women increases with increasing maternal age and BMI. Particularly, mothers aged 25 years or more have increased risk of GDM and the likelihood of GDM rises after 25 years of age. In our study, we found a similar trend finding a non-significant positive relationship between the two. Evidence around the world suggests maternal age and BMI as significant predictors for GDM. ${ }^{37}$ However, in our study, pregnant women aged 26-30 years only had a significantly increased likelihood of GDM, while BMI had no significant association. The increased risk of GDM in Muslim women (compared with Hindu women) could be due to differential social and behavioural culture, and or belief and health practices that were not investigated in this study. Family history of diabetes and current smoking status were significant predictors of GDM and findings were similar as reported in other studies. ${ }^{30} 3940$ However, unlike other studies, our study did not find any significant association between GDM and hypertension. ${ }^{38} 39$

Among GDM confirmed cases, a high fraction (34\%) were from APL category compared with non-GDM APL
Table 4 Crude and adjusted ORs (with Cls) of GDM in relation to other predictor variables

\begin{tabular}{|c|c|c|c|c|}
\hline \multirow[b]{2}{*}{ Variable } & \multicolumn{2}{|c|}{ Unadjusted } & \multicolumn{2}{|l|}{ Adjusted } \\
\hline & $\begin{array}{l}\text { OR } \\
\text { (95\% Cl) }\end{array}$ & $\begin{array}{l}P \\
\text { value }\end{array}$ & $\begin{array}{l}\text { OR } \\
(95 \% \mathrm{Cl})\end{array}$ & $\begin{array}{l}P \\
\text { value }\end{array}$ \\
\hline \multicolumn{5}{|l|}{ Age } \\
\hline $15-20$ years & 1 & & 1 & \\
\hline $21-25$ years & $\begin{array}{l}0.93(0.63 \\
\text { to } 1.37)\end{array}$ & 0.7 & $\begin{array}{l}1.00(0.54 \\
\text { to } 1.84)\end{array}$ & 0.99 \\
\hline 26-30 years ${ }^{*}$ & $\begin{array}{l}1.53(1.02 \\
\text { to } 2.30)\end{array}$ & 0.04 & $\begin{array}{l}1.70(1.14 \\
\text { to } 2.52)\end{array}$ & 0.01 \\
\hline$>30$ years & $\begin{array}{l}2.06(1.10 \\
\text { to } 3.87)\end{array}$ & 0.02 & $\begin{array}{l}2.33(0.78 \\
\text { to } 6.95)\end{array}$ & 0.13 \\
\hline \multicolumn{5}{|l|}{ Education } \\
\hline Illiterate & 1 & & 1 & \\
\hline Primary school & $\begin{array}{l}1.28(0.64 \\
\text { to } 2.57)\end{array}$ & 0.49 & $\begin{array}{l}1.28(0.52 \\
\text { to } 3.16)\end{array}$ & 0.58 \\
\hline 10th pass* & $\begin{array}{l}1.61(0.78 \\
\text { to } 3.32)\end{array}$ & 0.2 & $\begin{array}{l}1.58(1.05 \\
\text { to } 2.37)\end{array}$ & 0.03 \\
\hline 12th pass & $\begin{array}{l}1.62(0.75 \\
\text { to } 3.49)\end{array}$ & 0.22 & $\begin{array}{l}1.41(0.94 \\
\text { to } 2.11)\end{array}$ & 0.1 \\
\hline Graduate and above & $\begin{array}{l}2(0.84 \text { to } \\
4.82)\end{array}$ & 0.12 & $\begin{array}{l}1.47(0.62 \\
\text { to } 3.48)\end{array}$ & 0.38 \\
\hline
\end{tabular}

Religion

\begin{tabular}{|c|c|c|c|c|}
\hline Hindu & 1 & & 1 & \\
\hline Muslim & $\begin{array}{l}1.27(0.94 \\
\text { to } 1.72)\end{array}$ & 0.12 & $\begin{array}{l}1.52(1.05 \\
\text { to } 2.21)\end{array}$ & 0.03 \\
\hline Christian & $\begin{array}{l}0.5(0.06 \\
\text { to } 3.95)\end{array}$ & 0.52 & $\begin{array}{l}0.70(0.14 \\
\text { to } 3.45)\end{array}$ & 0.66 \\
\hline
\end{tabular}

Economic status

$\begin{array}{lllll}\begin{array}{l}\text { Below poverty line } \\ \text { (BPL) }\end{array} & 1 & & 1 \\ \begin{array}{l}\text { Above poverty line } \\ \text { (APL) }\end{array} & \begin{array}{l}1.56(1.13 \\ \text { to } 2.17)\end{array} & 0.01 & \begin{array}{l}1.38(1.00 \\ \text { to } 1.91)\end{array} & 0.05 \\ \begin{array}{l}\text { Body mass index } \\ \text { Normal }\end{array} & 1 & & & 1 \\ \text { Underweight } & \begin{array}{l}1.24(0.85 \\ \text { to } 1.82)\end{array} & 0.27 & \begin{array}{l}1.35(0.93 \\ \text { to } 1.96)\end{array} & 0.11 \\ \text { Overweight/ obese } & \begin{array}{l}1.64(1.07 \\ \text { to } 2.51)\end{array} & 0.02 & \begin{array}{l}1.38(0.90 \\ \text { to } 2.10)\end{array} & 0.13\end{array}$

\begin{tabular}{|c|c|c|c|}
\hline \multicolumn{4}{|l|}{ Gravida } \\
\hline Multigravida & 1 & & 1 \\
\hline Primigravida & $\begin{array}{l}0.95(0.70 \\
\text { to } 1.28)\end{array}$ & 0.72 & $\begin{array}{l}1.27(0.840 .25 \\
\text { to } 1.92)\end{array}$ \\
\hline
\end{tabular}

Haemoglobin status

\begin{tabular}{|c|c|c|c|c|}
\hline Anaemic & 1 & & 1 & \\
\hline Non-anaemic & $\begin{array}{l}1.52(1.05 \\
\text { to } 2.20)\end{array}$ & 0.03 & $\begin{array}{l}1.46(0.94 \\
\text { to } 2.26)\end{array}$ & 0.09 \\
\hline \multicolumn{5}{|l|}{ Diabetes in family } \\
\hline No & 1 & & 1 & \\
\hline Yes* & $\begin{array}{l}2.53(1.52 \\
\text { to } 4.22)\end{array}$ & 0 & $\begin{array}{l}1.82(1.08 \\
\text { to } 3.06)\end{array}$ & 0.02 \\
\hline
\end{tabular}

Miscarriage history 


\begin{tabular}{|c|c|c|c|c|}
\hline \multirow[b]{2}{*}{ Variable } & \multicolumn{2}{|c|}{ Unadjusted } & \multicolumn{2}{|l|}{ Adjusted } \\
\hline & $\begin{array}{l}\text { OR } \\
(95 \% \mathrm{Cl})\end{array}$ & $\begin{array}{l}P \\
\text { value }\end{array}$ & $\begin{array}{l}\text { OR } \\
(95 \% \mathrm{Cl})\end{array}$ & $\begin{array}{l}\mathbf{P} \\
\text { value }\end{array}$ \\
\hline No & 1 & & 1 & \\
\hline Yes & $\begin{array}{l}1.4(0.82 \\
\text { to } 2.37)\end{array}$ & 0.22 & $\begin{array}{l}1.53(0.93 \\
\text { to } 2.52)\end{array}$ & 0.09 \\
\hline \multicolumn{5}{|l|}{ Smoking status } \\
\hline Non-smokers & 1 & & 1 & \\
\hline Current smokers ${ }^{*}$ & $\begin{array}{l}1.94(0.85 \\
\text { to } 4.45)\end{array}$ & 0.13 & $\begin{array}{l}1.61(1.10 \\
\text { to } 2.35)\end{array}$ & 0.01 \\
\hline
\end{tabular}

Estimates were calculated using logistic regression with a robust cluster estimator of the variance in stata V.15.1. The clustered SE estimated with clustering at the zone level. *Significant variable in multivariate logistic regression. GDM, gestational diabetes mellitus.

women $(24 \%)$. This result is inconsistent with other studies where low socioeconomic status emerges as a significant risk factor for the development of type 2 diabetes mellitus. ${ }^{40}$ This may also be due to the fact our study sample is from rural areas where monthly disposable income is less than the national or state averages. ${ }^{27}$ Socioeconomic status and education had no significant effect on developing GDM which is in line with other studies finding no independent association between GDM, education and socioeconomic status. ${ }^{16}{ }^{41}$ A higher proportion of pregnant women in our study were anaemic $(83 \%)$. The rates of anaemia were disproportionately higher compared with state averages $(45.7 \%)$ and as reported in a local study $(72 \%)$ conducted in a rural block of Dibrugarh district of Assam state. ${ }^{41} 42$ This could be explained to poor dietary habits and local food culture among pregnant women. ${ }^{43}$ Further, we found an inverse relationship between anaemia and GDM adjusted for other variables and this finding aligns to as reported in other studies examining the association of GDM and anaemia. ${ }^{40}$

Our study is an attempt to define GDM prevalence estimates in rural Assam. This was possible because of three factors (1) unique presence and positioning of an extensive network of MMUs in rural Assam reaching to far-flung remote areas (2) government ownership and support for carrying field data collection. Auxiliary Nurse Midwives and ASHAs helped identification and mobilisation of pregnant women from the villages to respective MMU screening points located at public health facilities (3) presence of government MOs during screening helped in prompt treatment of GDM positive women and counselling support. Despite a large study, we faced certain definite challenges. First, due to resource constraints, we could not obtain a venous blood sample of pregnant women for glucose estimation. Second, maternal blood glucose estimation during the initial phase of pregnancy could not be assessed. This could have reinforced our findings. However, we tested maternal blood glucose before initiating OGTT. Additionally, we could not ascertain the reasons for the association of APL pregnant women with GDM due to unavailability of data. Further research is needed on this. However, despite its limitations, our study used a representative sample of all eligible pregnant women in rural Assam. A standardised gold standard OGTT confirmed the presence of GDM among pregnant women. In summary, MMUs are increasingly becoming an essential component in resource-constrained health systems. Such a unique model of healthcare service delivery both reach the difficult and underserved areas and has the potential to screen communicable and noncommunicable conditions and linking beneficiaries with the local healthcare for timely and prompt health interventions. $^{16}$

\section{CONCLUSIONS}

Our study gives first-hand estimates of GDM prevalence in rural Assam. A high prevalence of GDM in rural Assam warrants immediate government attention to safeguard the maternal and child health in the state. MMUs could be an option to initiate GDM screening in rural areas with appropriate compliance to guidelines and sufficient resource allocation.

\section{Author affiliations}

${ }^{1}$ Clinical Domain, Piramal Swasthya Management and Reseach Institute, Guwahati, Assam, India

${ }^{2}$ Research and Analysis Wing, Piramal Swasthya Management and Reseach Institute, Hyderabad, Telangana, India

${ }^{3}$ Assam and North East State Office, Piramal Swasthya Management and Reseach Institute, Guwahati, Assam, India

${ }^{4}$ Clinical Domain, Piramal Swasthya Management and Reseach Institute, Hyderabad, Telangana, India

${ }^{5}$ Innovations, Piramal Swasthya Management and Reseach Institute, Hyderabad, Telangana, India

\section{Twitter Vishal Dogra @drvishal1825}

Acknowledgements World diabetes foundation for funding the study. Government of Assam for ensuring smooth field operations. All pregnant women who participated in the study and front-line health workers who helped to identify and mobilise pregnant women from their residences.

Contributors SC, VD and SKH conceptualised the study. NH and HB supervised the field operations and data collection. SC cleaned the field data and wrote the first draft paper. VD performed the statistical analysis, interpreted the results and wrote the final manuscript. SKH, AKS and AV supervised the data transcription, and reviewed and edited the manuscript. All authors approved the final version of the manuscript.

Funding This work was supported by World Diabetes Foundation [Project-number WDF 15-956].

Competing interests None declared.

Patient consent for publication Not required.

Ethics approval Piramal Swasthya Management and Research Institute's institutional research ethics committee approved the study (letter no. PSMRI/2019/11 dated 11 May 2019). In addition, we took administrative approval from the Government of Assam for smooth field operations. Research participants were told the purpose of the study and provided written informed consent.

Provenance and peer review Not commissioned; externally peer reviewed.

Data availability statement Data are available upon reasonable request. Data can be requested from the corresponding author citing a reasonable request. 
Supplemental material This content has been supplied by the author(s). It has not been vetted by BMJ Publishing Group Limited (BMJ) and may not have been peer-reviewed. Any opinions or recommendations discussed are solely those of the author(s) and are not endorsed by BMJ. BMJ disclaims all liability and responsibility arising from any reliance placed on the content. Where the content includes any translated material, BMJ does not warrant the accuracy and reliability of the translations (including but not limited to local regulations, clinical guidelines, terminology, drug names and drug dosages), and is not responsible for any error and/or omissions arising from translation and adaptation or otherwise.

Open access This is an open access article distributed in accordance with the Creative Commons Attribution Non Commercial (CC BY-NC 4.0) license, which permits others to distribute, remix, adapt, build upon this work non-commercially, and license their derivative works on different terms, provided the original work is properly cited, appropriate credit is given, any changes made indicated, and the use is non-commercial. See: http://creativecommons.org/licenses/by-nc/4.0/.

\section{ORCID iD}

Vishal Dogra http://orcid.org/0000-0001-9725-5699

\section{REFERENCES}

1 Catalano PM, McIntyre HD, Cruickshank JK, et al. The hyperglycemia and adverse pregnancy outcome study: associations of GDM and obesity with pregnancy outcomes. Diabetes Care 2012;35:780-6.

2 Bhat M, K N R, Sarma SP, et al. Determinants of gestational diabetes mellitus: a case control study in a district tertiary care hospital in South India. Int J Diabetes Dev Ctries 2010;30:91-6.

3 Crowther CA, Hiller JE, Moss JR, et al. Effect of treatment of gestational diabetes mellitus on pregnancy outcomes. N Engl J Med 2005;352:2477-86.

4 Buchanan TA, Xiang AH, Page KA. Gestational diabetes mellitus: risks and management during and after pregnancy. Nat Rev Endocrinol 2012;8:639-49.

5 Damm P. Future risk of diabetes in mother and child after gestational diabetes mellitus. Int J Gynaecol Obstet 2009;104:S25-6.

6 Anjana RM, Deepa M, Pradeepa R, et al. Prevalence of diabetes and prediabetes in 15 states of India: results from the ICMR-INDIAB population-based cross-sectional study. Lancet Diabetes Endocrinol 2017:5:585-96.

7 Seshiah V, Balaji V, Balaji MS, et al. Prevalence of gestational diabetes mellitus in South India (Tamil Nadu)-a community based study. J Assoc Physicians India 2008;56:329-33.

8 Zargar AH, Sheikh MI, Bashir MI, et al. Prevalence of gestational diabetes mellitus in Kashmiri women from the Indian subcontinent. Diabetes Res Clin Pract 2004;66:139-45.

9 Maternal Health Division. Diagnosis \& management of gestational diabetes mellitus technical guidelines. New Delhi, 2018. https:// nhm.gov.in/New_Updates_2018/NHM_Components/RMNCH_MH_ Guidelines/Gestational-Diabetes-Mellitus.pdf

10 Kasthuri A. Challenges to healthcare in India - the five A's. Indian J Community Med 2018;43:141-3.

11 Seshiah V, Balaji V, Balaji MS, et al. Pregnancy and diabetes scenario around the world: India. Int J Gynaecol Obstet 2009;104:S35-8.

12 Saikia D, Das KK. Access to public health-care in the rural northeast India. Nehu J 2014;XII:77-100.

13 Mahalakshmi MM, Bhavadharini B, Maheswari K, et al. Comparison of maternal and fetal outcomes among Asian Indian pregnant women with or without gestational diabetes mellitus: a situational analysis study (WINGS-3). Indian J Endocrinol Metab 2016;20:491-6.

14 Hill C, Zurakowski D, Bennet J, et al. Knowledgeable neighbors: a mobile clinic model for disease prevention and screening in underserved communities. Am J Public Health 2012;102:406-10.

15 Dogra V, Hegde S, Rathnam N, et al. Large scale mobile medical service programme: data insights for strengthening local surveillance. Online J Public Health Inform 2019;11.

16 Binepal G, Agarwal P, Kaur N, et al. Screening difficult-to-reach populations for tuberculosis using a mobile medical unit, Punjab India. Public Health Action 2015;5:241-5.

17 Morano JP, Zelenev A, Lombard A, et al. Strategies for hepatitis C testing and linkage to care for vulnerable populations: point-of-care and standard HCV testing in a mobile medical clinic. J Community Health 2014;39:922-34.

18 Greenwald ZR, Fregnani JH, Longatto-Filho A, et al. The performance of mobile screening units in a breast cancer screening program in Brazil. Cancer Causes Control 2018;29:233-41.
19 Government of India, Registrar General \& Census Commissioner I. Census of India 2011: population, size and Decadal change, chapter 1. in: census 2011, 2013: 561-3.

20 Indian Institute of Population Sciences. District level household facility survey 4. Mumbai,, 2013. Available: http://rchiips.org/DLHS-4. html

21 International Institute for Population Sciences. National family health survey 4 Assam fact sheet. Mumbai, 2015. Available: http://rchiips. org/nfhs/pdf/NFHS4/AS FactSheet.pdf

22 Registrar General of India. Sample registration system. New Delhi, 2019. Available: http://censusindia.gov.in/vital_statistics/SRS_ Bulletins/SRS_Bulletin-Rate-2017-_May_2019.pdf

23 World Health Organization. The WHO STEPwise approach to noncommunicable disease risk factor surveillance (STEPS). Geneva. https://www.who.int/ncds/surveillance/steps/instrument/STEPS_ Instrument_V3.2.pdf

24 Polur H, Prasad K, Bandela P, et al. Diabetes in pregnancy Study group in India (DIPSI) - a novel criterion to diagnose GDM. Int $J$ Biochem Res Rev 2016;10:1-6.

25 World Health Organization. Definition, diagnosis and classification of diabetes mellitus and its complications. Part I: diagnosis and classification of diabetes mellitus WHO/MCD/MCS/99.2 ED. Geneva, 1999. https://apps.who.int/iris/bitstream/handle/10665/66040/WHO_ NCD_NCS_99.2.pdf?sequence $=1$

26 StataCorp. Stata statistical software: release 15 College Station. TX: StataCorp LP, 2017.

27 Ministry of Home Affairs. Census of India website: office of the registrar general \& census commissioner, India. dist. census handbook, 2011. Available: http://censusindia.gov.in/2011census/ dchb/Assam.html

28 Jesmin S, Akter S, Akashi H, et al. Screening for gestational diabetes mellitus and its prevalence in Bangladesh. Diabetes Res Clin Pract 2014;103:57-62.

29 A Khalil N. Screening for gestational diabetes among pregnant women attending a rural family health center- menoufia GovernorateEgypt. JFMHC 2017;3:6.

30 Seyoum B, Kiros K, Haileselase T, et al. Prevalence of gestational diabetes mellitus in rural pregnant mothers in northern Ethiopia. Diabetes Res Clin Pract 1999;46:247-51.

31 Bhatt AA, Dhore PB, Purandare VB, et al. Gestational diabetes mellitus in rural population of Western India - Results of a community survey. Indian J Endocrinol Metab 2015;19:507-10.

32 Mithal A, Bansal B, Kalra S. Gestational diabetes in India: science and society. Indian J Endocrinol Metab 2015;19:701-4.

33 Rajput M, Bairwa M, Rajput R. Prevalence of gestational diabetes mellitus in rural Haryana: a community-based study. Indian $\mathrm{J}$ Endocrinol Metab 2014;18:350-4.

34 Kalra P, Kachhwaha CP, Singh HV. Prevalence of gestational diabetes mellitus and its outcome in Western Rajasthan. Indian J Endocrinol Metab 2013;17:677.

35 Verma A, Singh B, Mengi V. Gestational diabetes in rural women of jammu. Indian J Community Med 2008;33:54-5.

36 Li KT, Naik S, Alexander M, et al. Screening and diagnosis of gestational diabetes in India: a systematic review and meta-analysis. Acta Diabetol 2018;55:613-25.

37 Erem C, Kuzu UB, Deger O, et al. Prevalence of gestational diabetes mellitus and associated risk factors in Turkish women: the Trabzon GDM study. Arch Med Sci 2015;11:724-35.

38 Fathy KNA, Mahmoud NS. Risk factors for gestational diabetes mellitus among pregnant women attending Monshaat Sultan family health center, Menoufia Governorate. Menoufia Med J 2018;31:640.

39 Leng J, Shao P, Zhang C, et al. Prevalence of gestational diabetes mellitus and its risk factors in Chinese pregnant women: a prospective population-based study in Tianjin, China. PLoS One 2015;10:e0121029.

40 Lao TT, Ho L-F. Impact of iron deficiency anemia on prevalence of gestational diabetes mellitus. Diabetes Care 2004;27:650-6.

41 Shen JJ, Tymkow C, MacMullen N. Disparities in maternal outcomes among four ethnic populations. Ethn Dis 2005;15:492-7.

42 Mahanta T, Deuri A, Mahanta B, et al. Maternal and foetal outcome of gestational diabetes mellitus in a rural block of Assam, India. Clin Epidemiol Glob Heal 2014;2:3-18.

43 Goswami RG, Thakur MB. Folk beliefs of food avoidance and prescription among menstruating and pregnant Karbi women of Kamrup district, Assam. J Ethn Food 2019;6:19. 